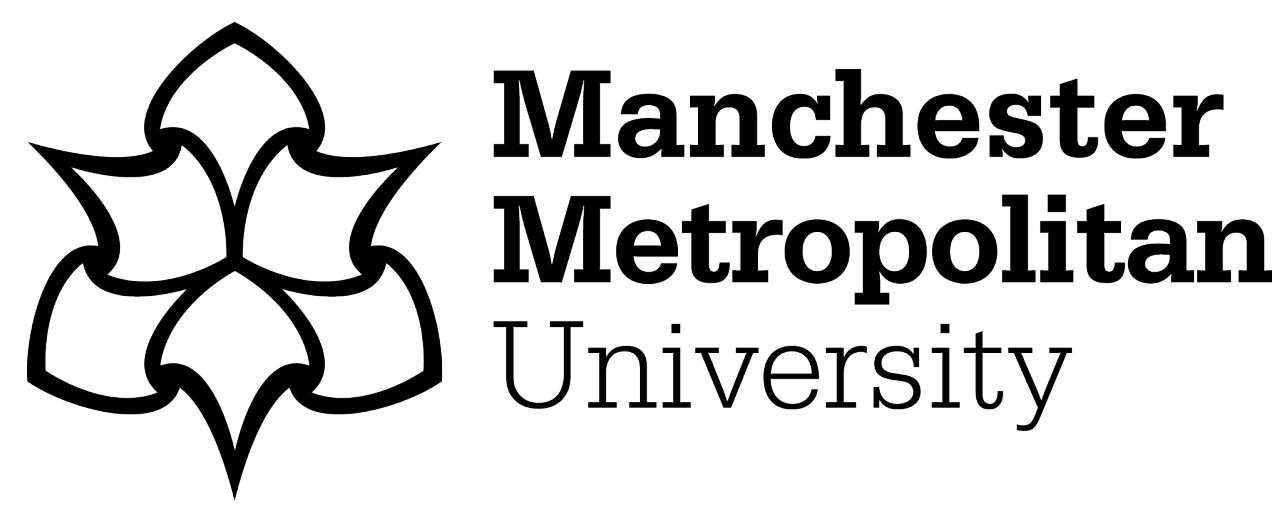

Leal Filho, W, Mandel, M, Al-Amin, AQ, Feher, A and Chiappetta Jabbour, CJ (2017) An assessment of the causes and consequences of agricultural land abandonment in Europe. International Journal of Sustainable Development \& World Ecology, 24 (6). pp. 554-560. ISSN 1350-4509

Downloaded from: https://e-space.mmu.ac.uk/618016/

Version: Accepted Version

Publisher: Taylor \& Francis

DOI: https://doi.org/10.1080/13504509.2016.1240113

Please cite the published version 
LEAL FILHO, W., MANDEL, M., AL-AMIN, A., FEHER, A., JABBOUR, C. J. C. (2016)

An assessment of the causes and consequences of agricultural land abandonment in Europe.

International Journal of Sustainable Development and World Ecology,

http://dx.doi.org/10.1080/13504509.2016.1240113

\title{
Review: An Assessment of the Causes and Consequences of Agricultural Land Abandonment in Europe
}

Walter Leal Filho ${ }_{1 *}$, Merit Mandel 2 , Abul Quasem Al-Amin 3 , Alexander Feher, , Charbel José Chiappetta Jabbour5

1.School of Science and the Environment, Manchester Metropolitan University, Chester Street, Manchester, M1 5GD, United Kingdom; *Corresponding author

E-mail: w.leal@mmu.ac.uk

2. Department of Geomatics, Estonian University of Life Sciences, Kreutzwaldi 5, Tartu 51014, Estonia

E-mail: merit.mandel@emu.ee

3. Universiti Tenaga Nasional (UNITEN), Malaysia

Email: amin.cantt@gmail.com

4. Slovakia University of Agriculture, Tr. A. Hlinku 2, SK- 94976 Nitra, Slovakia

E-mail:sandfeher@gmail.com

5. University of Stirling, FK9 4LA United Kingdom

E-mail: cjcjabbour@gmail.com

\begin{abstract}
The agriculture sector is the principal source of income for around 20\% of the EU-26 population, which live in predominantly rural regions that would be devastated without its contribution. Moreover, the combined agricultural and food sector forms an important part of the EU economy, accounting for 15 million jobs (8.3\% of total employment) and 4.4\% of GDP ((Europedia 2016). The 12 million active farmers across Europe today, have an average farm size of about 15 hectares, and are expected to meet the needs of 500 million Europeans. In addition, they are also expected to promote a sustainable and balanced development of their land, also in areas where production conditions are difficult. Yet, despite the relevance of the sector, the use of land for agriculture purposes is not very sustainable. Among other issues, there is a serious problem in respect of the abandonment of agricultural land. Based on the perceived need for research on this topic, the aim of this paper is to examine the causes and consequences of agricultural land abandonment, outlining its social, economic and environmental impacts, as well as the implications for territorial integration.
\end{abstract}


Keywords: agricultural land use, land abandonment, land losses, farmers, Europe 


\section{Introduction}

The sustainable use of land is a matter of primary concern to any country in the world. Indeed, sustainable land use is mentioned across many of the 17 Sustainable Development Goals (SDGs) .In particular, Goal 15 (Sustainably manage forests, combat desertification, halt and reverse land degradation, halt biodiversity loss) clearly states that there is a pressing need to fight deforestation and desertification, which not only pose major challenges to sustainable development,but also negatively affects the lives and livelihoods of millions of people in the fight against poverty. But one major threat to sustainable land use, is the issue of land abandonment. Therefore, apart from describing the problem and its scope, the paper also suggests some sustainability measures which may be adopted in order to ameliorate the problem.

Land abandonment is a term commonly used to describe uncultivated land ('Land used for agricultural purposes until recent times but not currently cultivated, with a noticeable cover of shrubs'), as abandoned land ('Land not subject to any cultivation practice (including conservation agriculture), nor intended for grazing'), neglected land (when they pose a threat to neighbour owners) (Rico 2011). Land abandonment is one possible outcome of a process of marginalisation driven by a combination of social, economic, political and environmental factors, by which certain areas of farmland cease to be viable under existing land use and socio-economic structures (Keenleyside and Tucker 2010).

Land abandonment often is a complex and gradual process, starting with a progressive marginalisation (i.e. withdrawal of land management) that leads initially to a reduction in farming intensity (e.g. lower stocking rates, withdrawal of grazing from the margins and infrequent cultivations) (Keenleyside and Tucker 2010). Farmland abandonment is a widespread land-use change in temperate regions, due to increasing yields on productive lands, conservation policies, and the increasing imports of agricultural products from other regions (Estelet al. 2015).Farmland abandonment (FLA) can be defined as the cessation of agricultural activities on a given surface of land and not taken by another activity (such as urbanisation or afforestation) (Pointereauet al. 2008).

The research importance of the topic can be assessed if one considers that, over last decades, large agricultural areas were abandoned worldwide, and relatively little research has focused on it. Agricultural or farmland abandonment is the process starting with withdrawal of agricultural management that leads initially to a reduction in farming intensity,and is followed by a progression of natural succession processes (Keenleyside and Tucker 2010a). However, it should be also noted that the literature provides more than one definition of the term, depending on the type of an used approach: administrative, social, ecological landscape or agronomic (Pointereau et al. 2008). For example, Joint Research Centre(JRC) defines farmland abandonment as'a significant decrease in management which leads to undesirable changes in ecosystem services'(Keenleyside and Tucker 2010a). 
Land abandonment is a serious problem in Africa, with serious climate implications (Tesfaye, Seifu 2016). In Europe, the problem is considered as one of the major environmental threats to territorial cohesion (Zakkak et al. 2015), since substantial areas have been affected by agricultural abandonment (Pointereau et al. 2008) The situation varies from a region to a region due to economic, social and demographic situation, natural conditions and historical development. Particularly, the problem is prominent in south-eastern Europe(Zakkak et al. 2015). During the 1990s millions of hectares of farmland (e.g. 15-20\% of cropland in Slovakia, Poland and Ukraine) were abandoned as a result of the transition process (Keenleyside and Tucker 2010a, van Dijk et al. 2004). Between years 2001 and 2012, up to 7.6 Mha of agricultural land was abandoned, in Eastern Europe, Southern Scandinavia, and Europe's mountain regions (Estel et al. 2015). The analysis of the 2004-06 Rural Development Programmes has shown that as a result of poor soils and unfavourable economic conditions $17.6 \%$ of the agricultural land was abandoned in Poland, 10.1\%, in Estonia, 21.1\% in Latvia and 10.3\% in Lithuania (van Dijk et al. 2004).

A wide range of studies introduces different drivers, causes, indices of farmland abandonment. Mostly are the result of environmental and socio-economic changes (Cramer et al. 2008). The following drivers are often named as the most common:

- Rural-urban migration stimulated by cultural attraction and new economic opportunities in cities(Aide and Grau 2004), or asa result of armed conflicts, political instability, or largescale natural catastrophes e.g. hurricanes (Aide and Grau 2004, Zakkak et al. 2015).

- Ecological drivers such as elevation, geological substrate, slope, fertility, soil depth, climate change, soil erosion as a consequence of land mismanagement and/or overexploitation, when they constrain agricultural production (Rey Benayas et al. 2007).

- An increase of yields on productive lands, conservation policies, and the increasing imports of agricultural products from other regions (Estel et al. 2015).

- Reduction of the profitability of farming enterprises e.g. a decrease of crop prices makes it very difficult for small-scale farmers to compete (Aide and Grau 2004, Keenleyside and Tucker 2010a).

- Technology, industrialization, landtenure systems, security, accessibility (e.g. roads) and proximity to cities (Rey Benayas et al. 2007).

- Small-scale, family farms closing, lack of economic and demographic viability, low mobility of land market (Rico 2011).

- Reduction of landscape heterogeneity and promotion of vegetation;

- homogenisation, often associated with increased fire frequency;

- reduction of water stocks, biodiversity loss and reduced population of adapted species and loss of cultural and aesthetic values (Benayas et al. 2007).

The causes of agricultural land abandonment in Europe are manifold, depending on the area and the period under consideration (Pointereau et al. 2008, Terres et al. 2015).JRC classified the recurrent determinants of farmland abandonment in EU into three blocks(Terres et al. 2013): 
1. Poor environmental / biophysical suitability for agricultural activity;

2. Low farm stability and viability ;

3. Negative drivers from regional context.

In addition to the aforementioned general key drivers, experts have pointed out such causes as share of subsidies from the Common Agricilture Policy (CAP) in the income, low investments on the farm, age of a farm holder, lower farmer qualification, and weak land market (Terres et al. 2013).Pointereau et al. (2008) also talk about historical factors e.g. transition to free market economies with a breakdown of the gricultural economy during the 1990-2004 period inEastern European countries, national and EU policies e.g. problems in renewing agri-environment contracts after 5 years duration, new CAP sanitary requirements from in eastern European countries since 2004, and decoupling of direct payments from a product (Pointereau et al. 2008). Basically, these analyses point to ways in which the application of policies for economic purposes may have (unintended) impacts upon marginal areas because of their particular socio-economic and environmental characteristics, which reduce the viability of farming or otherwise commercially managing these areas, leading to their abandonment.

\section{Implications of land abandonment}

The consequences of farmland abandonment are very diverse across the EU, and have serious implications for biodiversity and ecosystem function (Munroe et al. 2013). However, it is important to note that at the same time they can be considered as potentially negative or positive(Eurostat 2013).

\section{Positive}

Among the benefits of land abandonment, the following elements have been identified:

- An opportunity to restore an historical vegetation state (Cramer et al. 2008).

- Facilitation of ecosystem recovery. The recovering ecosystems may provide ecological services for the growing urban population and could support biodiversity (Aide and Grau 2004).

- Passive revegetation and active reforestation(Rey Benayas et al. 2007).

- An opportunity for significant large-scale restoration of non-agricultural habitats (e.g.rewilding) (Keenleyside and Tucker 2010a).

- Water regulation(Rey Benayas et al. 2007).

- Increased carbon sequestration as a result of vegetation regrowth (Munroe et al. 2013).

- Soil recoveryalong with nutrient cycling (Rey Benayas et al. 2007).

- A reduction in agricultural chemicals pollution for areasthat were previously intensively managed (Pointereau et al. 2008).

\section{Negative}


In many other circumstances abandonment may be damaging. Among the negative implicationslinked to the abandonment of agricultural land,the following may be mentioned:

- Reduction of landscape heterogeneity and promotion of vegetation homogenisation (Rey Benayas et al. 2007).

- Alteration ofecosystem processes (Cramer et al. 2008).

- Soil erosion and desertification(Rey Benayas et al. 2007).

- Threat to a range of semi-natural habitats and associated species of nature conservation importance, many of which are concentrated in Natura 2000 sites or are High Nature Value (HNV) farmland (Keenleyside and Tucker 2010a) that resulted in lower conservation value of this type of land (Pointereau et al. 2008).

- Reduction of water availability(Rey Benayas et al. 2007).

- Significant biodiversity loss and reduced population of adapted species. For example, end of low fertiliser input, andgrazing or mowing negatively affects species that are dependent on such activities(Pointereau et al. 2008).

- Loss of cultural and aesthetic values(Rey Benayas et al. 2007).

- Increase of wildfire frequency and intensity(Moreira and Russo 2007).

Unfortunately, such issues are seldom tackled in the curriculum (Dmochowski, Garofalo, Fisher, Greene, Gambogi 2016), hence good opportunties for the training of students are being missed.

\section{Examples of abandoned agricultural areas in Europe}

A review of abandoned agricultural areas is based on publications in English. A systematic search in ScienceDirect database (Search all fields = (agricultural land abandonment) or Search all fields = (farmland abandonment); Year = $2000-2016$; Topic $=$ Europe + Agriculture) resulted in 433 potentially relevant papers. After screening the title, abstract and case study area, 23 were finally selected for this study. We included publications that specified case study area or reported the rate or amount of abandoned agricultural area. ScienceDirect database was selected, because it is full-text database which makes the screening process faster and easier.

\section{Figure 1 here}

The authors identified 36 case studies from the selected publications. Case study areas varied from $13 \mathrm{~km}^{2}$ to 10 million $\mathrm{km}^{2}$, with median of $255 \mathrm{~km}^{2} .74 \%$ of the studies were published after 2010 . The timespan of the case studies was 1782 to 2012. The median start year of case study periods is 1988 and the median end year is 2007. Most of the studies (19) were long period studies -

abandonment was measured more than 10 years back in time. The study period ranged from 1 to 224 
years, with an average of 29 years. Abandonment rates varied from 44.56 ha to 46.1 Mha, or 1.5 \%to $45 \%$ of the agricultural land area within the territory.

When looking at the causes or drivers of agricultural land abandonment, socio-economic and ecological drivers are dominant in the selected studies (Table 1). Division of the abandonment drivers is synthesised based on (Rey Benayas et al. 2007)and (Pointereau et al. 2008). Only onefourth of the studies mentioned policy-driven factors. A Latvian case study (Abolina and Luzadis 2015) highlighted that socio-economic drivers have greater effect upon land abandonment than environmental or biophysical factors. A similar conclusion is supported by a study (Gellrich and Zimmermann 2007) in Swiss mountain areas where land abandonment is driven by migration and income decline from agriculture. In a Slovakian case study (Pazúr et al. 2014) ecological factors (e.g. soil quality, higher slopes, accessibility) were important for determining the location and extent of land abandonment, but these acted in combination with socio-economic changes. In essence, because abandonment signifies a change in land use, it generally links to changes in wider circumstances which are more often socio-economic or anthropogenic in nature than purely the result of biophysical change. Often, these changes can be linked to policies.(Prishchepov et al. 2013) and (Corbelle-Rico et al. 2015) both concluded the importance of policies in relation to land abandonment and future land use.

\section{Table 1 here}

Drawing out the possible consequences of agricultural land abandonment seems to have faded into the background as a focus in selected studies. One reason may be the lack of data and methodology for how to assess or attribute the possible consequences of the land abandonment. According to the Zaragozí et al. (2012) and (Rey Benayas 2007) land abandonment may have positive or negative effectsupon future land use. Findings of possible consequences from the selected literature (Table 2) coincide with those mentioned in section 2'Implication of land abandonment'. Depending on the study site, the positive or negative effects of the consequence may vary. For example, agricultural land abandonment may have positive effectsupon soil erosion in hilly areas (Bakker et al. 2008) and negative effects on dry regions (Rey Benayas 2007). In selected studies, environmental consequences (e.g. biodiversity loss, revegetation, soil erosion and wildfire risks) are more recorded than socio-economic ones (e.g. rural depopulation, changes in local economy, renewable energy potential). According to (Milenov et al. 2014) agricultural land abandonment may have a snowball effect on the local economy through structural changes and decreasing demand for labour skills leading to further land abandonment. Income reduction from agriculture (Kanianska et al. 2014) may lead to outmigration (Baumann et al. 2011) from the rural areas unbalancing rural communities and thus stimulating further decline.

\section{Table 2 here}


Another aspect of the agricultural land abandonment studies is the location of the case study sites. At first sight, it may seem that it is a well studied topic. While looking little bit deeper, it appears that several publications are based on the same study areas with different perspectives (e.g. Corbelle-Rico et al. 2012, Corbelle-Rico et al. 2015, Gellrich and Zimmermann 2007, Gellrich et al. 2007). The limited location aspect is emphasised by (Hatna and Bakker 2011) as most studies are based on small areas, biased towards marginal areas. Selected study sites are located in areas where land abandonment is estimated to occur - European mountain areas, areas with poor soils and harsh climate (Keenleyside and Tucker 2010b). (Kowicki 2008) was one the few finding that abandonment of agricultural areas took place in the vicinity of large cities, where a whole range of different drivers are in play. The proximity of the city sets a pressure for land use change, setting it aside for speculative development purposes (Vanwambeke et al. 2012), as agricultural land becomes attractive to real estate developers (Lieskovsky et al. 2013). This is an aspect meriting further consideration in future abandonment studies.

\section{Measures to Mitigate Land Abandonment}

As discussed above, the consequences of land abandonment and their significant impact on various fields attractconsiderable attention from policy makers at national and EU level (Eurostat, 2013).The main discussion point regarding the measures addressing the problem is the environmental trade-off between its negative or positive implications. Therefore, it is not always an EU priority to bring abandoned land back into production(van Dijk et al. 2004).

There is a diversity of drivers of agricultural abandonment, which are closed related to pathways of land use change. Some of them are: relationship to fire, damages to landscape management and influences to biodiversity. In addition, a diversity of policies have been playing a role in reducing the portions of land are being abandoned.

For instance, the common agricultural policy (CAP) includes environmental requirements attached to the necessary management of agricultural land and offers two main instruments to avoid land abandonment (decoupled direct payments and compensatory payments in Areas of Natural Constraints). The first contributes to stabilizing and enhancing farm income, whereas the second helps maintain farming activity in areas which, due to adverse natural conditions, are less profitable(Eurostat, 2013).In addition cross-compliance measures applied to direct paymentsrequire landowners to maintain agricultural land in 'good agricultural and environmental condition' and thus reduce the risks of complete abandonment (Keenleyside and Tucker 2010a).Therefore, many experts anticipate a higher level of land abandonment as a result of reduced levels of CAP support for extensive farming (Terres et al. 2013).

To supportareas that are designated as High Nature Value (HNV) farmland i.e. to ensure preservation of their biodiversity value, restoration activities, including removal of unwanted vegetation, need to be undertaken (van Dijk et al. 2004).There are also a number of EU policies that 
support the management of abandoned land for the benefit of biodiversity, e.g. theHabitats and Birds Directives and the Biodiversity Plan for Agriculture (van Dijk et al. 2004). Another alternative approach to the management of such land is rewilding. Navarro and Pereira (2012) argue that it should be recognized by policy-makers as one of the possible land management options in Europe, particularly on marginal areas. The approach covers change in ecosystems and aims at restoring ecological dynamics. The important point is that rewilding does not target to conserve species occurrences, but to allow natural processes to regain dominance in landscapes (Pereira and Navarro 2015).

It should be noted that some measures focused on agro-environmental services and forest regeneration e.g. payments for environmental service(s) (PES) systems, may actually subsidise and accelerate the abandonment of marginal agricultural areas (Sierra and Russman 2006, Wunder et al., 2005).

\section{Conclusions}

Land abandonment is a major barrier to sustainable development efforts in rural areas for three main reasons: uncultivated land allows the uncontrolled growth of shrubs and many undesired plants, instead of organised biodiversity planning, it makes the land more vulnerable to fire, and in some occasions, to soil erosion. Land abandonment also means possible losses of income to people living in such areas.

As outlined in this paper, land abandonment is a dynamic process driven by many factors including time span, region, and historical development(Keenleyside and Tucker 2010a). According to projections, there is likely to be significant levels of farmland abandonment in Europe over the next 20 - 30 years (Terres et al. 2013).However, these projections may be unsafe as they do not fully rely upon scientific evidence, which demonstrates potential issues of bias due to repeat sampling and an under-representation of non-marginal areas.

As this paper has shown, land abandonment can pose a major threat to sustainable land use in particular and to the sustainable development of rural areas as a whole. It therefore needs to be addressed, as a matter of urgency, so that its consequences in the medium and long-term may be avoided.

Furthermore, the measures most suitable for addressing the phenomenon are strongly dependent on government choice, whether to support the positive environmental implications or to tackle the negative consequences.

\section{Acknowledgements}

The authors gratefully acknowledge Janet Dwyerfor her comments to an early draft of this paper. 


\section{References}

Abolina, E., Luzadis, V.A., 2015. Land Use Policy Abandoned agricultural land and its potential for short rotation woody crops in Latvia. Land use policy 49, 435-445.

doi:10.1016/j.landusepol.2015.08.022

Abolina, E., Volk, T.A., Lazdina, D., 2015. GIS based agricultural land availability assessment for the establishment of short rotation woody crops in Latvia. Biomass and Bioenergy 72, 263272. doi:10.1016/j.biombioe.2014.10.026Abolina, E., Luzadis, V.A., 2015. Land Use Policy Abandoned agricultural land and its potential for short rotation woody crops in Latvia. Land use policy 49, 435-445. doi:10.1016/j.landusepol.2015.08.022

Abolina, E., Volk, T.A., Lazdina, D., 2015. GIS based agricultural land availability assessment for the establishment of short rotation woody crops in Latvia. Biomass and Bioenergy 72, 263272. doi:10.1016/j.biombioe.2014.10.026

Aide, T.M., Grau, H.R., 2004. Globalization, Migration, and Latin American Ecosystems. Science (80-. ). 305, 1915-1916.

Bakker, M.M., Govers, G., van Doorn, A., Quetier, F., Chouvardas, D., Rounsevell, M., 2008. The response of soil erosion and sediment export to land-use change in four areas of Europe: The importance of landscape pattern. Geomorphology 98, 213-226.

doi:10.1016/j.geomorph.2006.12.027

Bakker, M.M., van Doorn, A.M., 2009. Farmer-specific relationships between land use change and landscape factors: Introducing agents in empirical land use modelling. Land use policy 26, 809-817. doi:10.1016/j.landusepol.2008.10.010

Baumann, M., Kuemmerle, T., Elbakidze, M., Ozdogan, M., Radeloff, V.C., Keuler, N.S., Prishchepov, A. V., Kruhlov, I., Hostert, P., 2011. Patterns and drivers of post-socialist farmland abandonment in Western Ukraine. Land use policy 28, 552-562.

doi:10.1016/j.landusepol.2010.11.003

Beilin, R., Lindborg, R., Stenseke, M., Pereira, H.M., Llausàs, A., Slätmo, E., Cerqueira, Y., Navarro, L., Rodrigues, P., Reichelt, N., Munro, N., Queiroz, C., 2014. Analysing how drivers of agricultural land abandonment affect biodiversity and cultural landscapes using case studies from Scandinavia, Iberia and Oceania. Land use policy 36, 60-72.

doi:10.1016/j.landusepol.2013.07.003

Cocca, G., Sturaro, E., Gallo, L., Ramanzin, M., 2012. Is the abandonment of traditional livestock farming systems the main driver of mountain landscape change in Alpine areas? Land use policy 29, 878-886. doi:10.1016/j.landusepol.2012.01.005

Corbelle-Rico, E., Butsic, V., Enríquez-García, M.J., Radeloff, V.C., 2015. Technology or policy? Drivers of land cover change in northwestern Spain before and after the accession to European Economic Community. Land use policy 45, 18-25. doi:10.1016/j.landusepol.2015.01.004

Corbelle-Rico, E., Crecente-Maseda, R., Santé-Riveira, I., 2012. Multi-scale assessment and spatial modelling of agricultural land abandonment in a European peripheral region: Galicia (Spain), 1956-2004. Land use policy 29, 493-501. doi:10.1016/j.landusepol.2011.08.008 
Cramer, V., Hobbs, R., Standish, R., 2008. What's new about old fields? Land abandonment and ecosystem assembly. Trends Ecol. Evol. 23, 104-112. doi:10.1016/j.tree.2007.10.005

Dmochowski, J.E., Garofalo, D., Fisher, S. Greene, A., Gambogi, D. 2016. Integrating sustainability across the university curriculum. International Journal of Sustainability in Higher Education, 17 (5), pp.652-670.

Estel, S., Kuemmerle, T., Alcántara, C., Levers, C., Prishchepov, A., Hostert, P., 2015. Mapping farmland abandonment and recultivation across Europe using MODIS NDVI time series. Remote Sens. Environ. 163, 312-325. doi:10.1016/j.rse.2015.03.028

Europedia (2016): http://www.europedia.moussis.eu/books/Book_2/6/21/index.tkl?all=1\&pos=299).

Eurostat, 2013. Agri-environmental indicator - risk of land abandonment [WWW Document].

Gellrich, M., Baur, P., Koch, B., Zimmermann, N.E., 2007. Agricultural land abandonment and natural forest re-growth in the Swiss mountains: A spatially explicit economic analysis. Agric. Ecosyst. Environ. 118, 93-108. doi:10.1016/j.agee.2006.05.001

Gellrich, M., Zimmermann, N.E., 2007. Investigating the regional-scale pattern of agricultural land abandonment in the Swiss mountains: A spatial statistical modelling approach. Landsc. Urban Plan. 79, 65-76. doi:10.1016/j.landurbplan.2006.03.004

Hatna, E., Bakker, M.M., 2011. Abandonment and Expansion of Arable Land in Europe. Ecosystems 14, 720-731. doi:10.1007/s10021-011-9441-y

Kanianska, R., Kizeková, M., Nováček, J., Zeman, M., 2014. Land-use and land-cover changes in rural areas during different political systems: A case study of Slovakia from 1782 to 2006. Land use policy 36, 554-566. doi:10.1016/j.landusepol.2013.09.018

Keenleyside, C., Tucker, G., 2010a. Farmland Abandonment in the EU: an Assessment of Trends and Prospects. London, UK.

Keenleyside, C., Tucker, G., 2010b. Farmland Abandonment in the EU: an Assessment of Trends and Prospects. London: WWF and IEEP. 93.

Kosmas, C., Kairis, O., Karavitis, C., Acikalin, S., Alcalá, M., Alfama, P., Atlhopheng, J., Barrera, J., Belgacem, a., Solé-Benet, a., Brito, J., Chaker, M., Chanda, R., Darkoh, M., Ermolaeva, O., Fassouli, V., Fernandez, F., Gokceoglu, C., Gonzalez, D., Gungor, H., Hessel, R., Khatteli, H., Khitrov, N., Kounalaki, a., Laouina, a., Magole, L., Medina, L., Mendoza, M., Mulale, K., Ocakoglu, F., Ouessar, M., Ovalle, C., Perez, C., Perkins, J., Pozo, a., Prat, C., Ramos, a., Ramos, J., Riquelme, J., Ritsema, C., Romanenkov, V., Sebego, R., Sghaier, M., Silva, N., Sizemskaya, M., Sonmez, H., Taamallah, H., Tezcan, L., de Vente, J., Zagal, E., Zeiliguer, a., Salvati, L., 2014. An exploratory analysis of land abandonment drivers in areas prone to desertification. Catena. doi:10.1016/j.catena.2014.02.006 
Lieskovsky, J., Kanka, R., Bezak, P., Stefunkova, D., Petrovic, F., Dobrovodska, M., 2013. Driving forces behind vineyard abandonment in Slovakia following the move to a market-oriented economy. Land use policy 32, 356-365. doi:10.1016/j.landusepol.2012.11.010

Łowicki, D., 2008. Land use changes in Poland during transformation. Case study of Wielkopolska region. Landsc. Urban Plan. 87, 279-288. doi:10.1016/j.landurbplan.2008.06.010

Milenov, P., Vassilev, V., Vassileva, A., Radkov, R., Samoungi, V., Dimitrov, Z., Vichev, N., 2014. Monitoring of the risk of farmland abandonment as an efficient tool to assess the environmental and socio-economic impact of the Common Agriculture Policy. Int. J. Appl. Earth Obs. Geoinf. 32, 218-227. doi:10.1016/j.jag.2014.03.013

Moreira, F., Russo, D., 2007. Modelling the impact of agricultural abandonment and wildfires on vertebrate diversity in Mediterranean Europe. Landsc. Ecol. 22, 1461-1476.

Mottet, A., Ladet, S., Coqué, N., Gibon, A., 2006. Agricultural land-use change and its drivers in mountain landscapes: A case study in the Pyrenees. Agric. Ecosyst. Environ. 114, 296-310. doi:10.1016/j.agee.2005.11.017

Munroe, D.K., van Berkel, D.B., Verburg, P.H., Olson, J.L., 2013. Alternative trajectories of land abandonment: Causes, consequences and research challenges. Curr. Opin. Environ. Sustain. 5, 471-476. doi:10.1016/j.cosust.2013.06.010

Navarro, L.M., Pereira, H.M., 2012. Rewilding Abandoned Landscapes in Europe. Ecosystems 15, 900-912. doi:10.1007/s10021-012-9558-7

Pazúr, R., Lieskovský, J., Feranec, J., Ot’ahel', J., 2014. Spatial determinants of abandonment of large-scale arable lands and managed grasslands in Slovakia during the periods of post-socialist transition and European Union accession. Appl. Geogr. 54, 118-128.

doi:10.1016/j.apgeog.2014.07.014

Pereira, H., Navarro, L., 2015. Preface, in: Pereira, H.M., Navarro, L.M. (Eds.), Rewilding European Landscapes. Springer Heidelberg New York Dordrecht London, pp. v-X. doi:10.1007/978-3-319-12039-3

Pointereau, P., Coulon, F., Girard, P., Lambotte, M., Stuczynski, T., Sánchez Ortega, V., Del Rio, A., 2008. Analysis of the Driving Forces behind Farmland Abandonment and the Extent and Location of Agricultural Areas that are Actually Abandoned or are in Risk to be Abandoned.

Prishchepov, A. a., Müller, D., Dubinin, M., Baumann, M., Radeloff, V.C., 2013. Determinants of agricultural land abandonment in post-Soviet European Russia. Land use policy 30, 873-884. doi:10.1016/j.landusepol.2012.06.011

Rey Benayas, J., 2007. Abandonment of agricultural land: an overview of drivers and consequences. CAB Rev. Perspect. Agric. Vet. Sci. Nutr. Nat. Resour. 2. doi:10.1079/PAVSNNR20072057

Rey Benayas, J.M., Martins, A., Nicolau, J.M., Schulz, J.J., 2007. Abandonment of agricultural land: an overview of drivers and consequences. CAB Rev. Perspect. Agric. Vet. Sci. Nutr. Nat. Resour. 2. doi:10.1079/PAVSNNR20072057

Sierra, R., Russman, E., 2006. On the efficiency of environmental service payments: A forest conservation assessment in the Osa Peninsula, Costa Rica. Ecol. Econ. 59, 131-141. 
doi:10.1016/j.ecolecon.2005.10.010

Zakkak, S., Radovic, A., Nikolov, S.C., Shumka, S., Kakalis, L., Kati, V., 2015. Assessing the effect of agricultural land abandonment on bird communities in southern-eastern Europe. J. Environ. Manage. 164, 171-179. doi:10.1016/j.jenvman.2015.09.005

Zaragozí, B., Rabasa, A., Rodríguez-Sala, J.J., Navarro, J.T., Belda, A., Ramón, A., 2012. Modelling farmland abandonment: A study combining GIS and data mining techniques. Agric. Ecosyst. Environ. 155, 124-132. doi:10.1016/j.agee.2012.03.019

Terres, J.-M., Nisini, L., Anguiano, E., 2013. Assessing the risk of farmland abandonment in the EU. doi:10.2788/81337

Terres, J.-M., Scacchiafichi, L.N., Wania, A., Ambar, M., Anguiano, E., Buckwell, A., Coppola, A., Gocht, A., Källström, H.N., Pointereau, P., Strijker, D., Visek, L., Vranken, L., Zobena, A., 2015. Farmland abandonment in Europe: Identification of drivers and indicators, and development of a composite indicator of risk. Land use policy 49, 20-34. doi:10.1016/j.landusepol.2015.06.009

van der Sluis, T., Pedroli, B., Kristensen, S.B.P., Lavinia Cosor, G., Pavlis, E., 2015. Changing land use intensity in Europe - Recent processes in selected case studies. Land use policy. doi:10.1016/j.landusepol.2014.12.005

van Dijk, G., Zdanowicz, A., Blokzijl, R., 2004. Land abandonment, biodiversity and the CAP, Land abandonment and biodiversity, in relation to the 1st and 2nd pillars of the e $\mathrm{u}$ 's Common Agricultural Policy; outcome of an international seminar in Sigulda, Latvia, 7-8 October, 2004. Utrecht, Netherlands.

Vanwambeke, S.O., Meyfroidt, P., Nikodemus, O., 2012. From USSR to EU: 20 years of rural landscape changes in Vidzeme, Latvia. Landsc. Urban Plan. 105, 241-249. doi:10.1016/j.landurbplan.2011.12.009

Wunder, S., The Dung, B., Ibarra, E., 2005. Payment is good, control is better: Why payments for environmental services in vietnam have so far remained incipient, Cifor.Org. Bogor Barat, Indonesia.

Abolina, E., Luzadis, V.A., 2015. Land Use Policy Abandoned agricultural land and its potential for short rotation woody crops in Latvia. Land use policy 49, 435-445. doi:10.1016/j.landusepol.2015.08.022

Abolina, E., Volk, T.A., Lazdina, D., 2015. GIS based agricultural land availability assessment for the establishment of short rotation woody crops in Latvia. Biomass and Bioenergy 72, 263272. doi:10.1016/j.biombioe.2014.10.026

Aide, T.M., Grau, H.R., 2004. Globalization, Migration, and Latin American Ecosystems. Science (80-. ). 305, 1915-1916.

Bakker, M.M., Govers, G., van Doorn, A., Quetier, F., Chouvardas, D., Rounsevell, M., 2008. The response of soil erosion and sediment export to land-use change in four areas of Europe: The importance of landscape pattern. Geomorphology 98, 213-226. 
doi:10.1016/j.geomorph.2006.12.027

Bakker, M.M., van Doorn, A.M., 2009. Farmer-specific relationships between land use change and landscape factors: Introducing agents in empirical land use modelling. Land use policy 26, 809-817. doi:10.1016/j.landusepol.2008.10.010

Baumann, M., Kuemmerle, T., Elbakidze, M., Ozdogan, M., Radeloff, V.C., Keuler, N.S., Prishchepov, A. V., Kruhlov, I., Hostert, P., 2011. Patterns and drivers of post-socialist farmland abandonment in Western Ukraine. Land use policy 28, 552-562. doi:10.1016/j.landusepol.2010.11.003

Beilin, R., Lindborg, R., Stenseke, M., Pereira, H.M., Llausàs, A., Slätmo, E., Cerqueira, Y., Navarro, L., Rodrigues, P., Reichelt, N., Munro, N., Queiroz, C., 2014. Analysing how drivers of agricultural land abandonment affect biodiversity and cultural landscapes using case studies from Scandinavia, Iberia and Oceania. Land use policy 36, 60-72. doi:10.1016/j.landusepol.2013.07.003

Cocca, G., Sturaro, E., Gallo, L., Ramanzin, M., 2012. Is the abandonment of traditional livestock farming systems the main driver of mountain landscape change in Alpine areas? Land use policy 29, 878-886. doi:10.1016/j.landusepol.2012.01.005

Corbelle-Rico, E., Butsic, V., Enríquez-García, M.J., Radeloff, V.C., 2015. Technology or policy? Drivers of land cover change in northwestern Spain before and after the accession to European Economic Community. Land use policy 45, 18-25. doi:10.1016/j.landusepol.2015.01.004

Corbelle-Rico, E., Crecente-Maseda, R., Santé-Riveira, I., 2012. Multi-scale assessment and spatial modelling of agricultural land abandonment in a European peripheral region: Galicia (Spain), 1956-2004. Land use policy 29, 493-501. doi:10.1016/j.landusepol.2011.08.008

Cramer, V., Hobbs, R., Standish, R., 2008. What's new about old fields? Land abandonment and ecosystem assembly. Trends Ecol. Evol. 23, 104-112. doi:10.1016/j.tree.2007.10.005

Estel, S., Kuemmerle, T., Alcántara, C., Levers, C., Prishchepov, A., Hostert, P., 2015. Mapping farmland abandonment and recultivation across Europe using MODIS NDVI time series. Remote Sens. Environ. 163, 312-325. doi:10.1016/j.rse.2015.03.028

Eurostat, 2013. Agri-environmental indicator - risk of land abandonment [WWW Document].

Gellrich, M., Baur, P., Koch, B., Zimmermann, N.E., 2007. Agricultural land abandonment and natural forest re-growth in the Swiss mountains: A spatially explicit economic analysis. Agric. Ecosyst. Environ. 118, 93-108. doi:10.1016/j.agee.2006.05.001

Gellrich, M., Zimmermann, N.E., 2007. Investigating the regional-scale pattern of agricultural land abandonment in the Swiss mountains: A spatial statistical modelling approach. Landsc. Urban Plan. 79, 65-76. doi:10.1016/j.landurbplan.2006.03.004

Hatna, E., Bakker, M.M., 2011. Abandonment and Expansion of Arable Land in Europe. Ecosystems 14, 720-731. doi:10.1007/s10021-011-9441-y

Kanianska, R., Kizeková, M., Nováček, J., Zeman, M., 2014. Land-use and land-cover changes in rural areas during different political systems: A case study of Slovakia from 1782 to 2006.

Land use policy 36, 554-566. doi:10.1016/j.landusepol.2013.09.018 
Keenleyside, C., Tucker, G., 2010a. Farmland Abandonment in the EU: an Assessment of Trends and Prospects. London, UK.

Keenleyside, C., Tucker, G., 2010b. Farmland Abandonment in the EU: an Assessment of Trends and Prospects. London: WWF and IEEP. 93.

Kosmas, C., Kairis, O., Karavitis, C., Acikalin, S., Alcalá, M., Alfama, P., Atlhopheng, J., Barrera, J., Belgacem, a., Solé-Benet, a., Brito, J., Chaker, M., Chanda, R., Darkoh, M., Ermolaeva, O., Fassouli, V., Fernandez, F., Gokceoglu, C., Gonzalez, D., Gungor, H., Hessel, R., Khatteli, H., Khitrov, N., Kounalaki, a., Laouina, a., Magole, L., Medina, L., Mendoza, M., Mulale, K., Ocakoglu, F., Ouessar, M., Ovalle, C., Perez, C., Perkins, J., Pozo, a., Prat, C., Ramos, a., Ramos, J., Riquelme, J., Ritsema, C., Romanenkov, V., Sebego, R., Sghaier, M., Silva, N., Sizemskaya, M., Sonmez, H., Taamallah, H., Tezcan, L., de Vente, J., Zagal, E., Zeiliguer, a., Salvati, L., 2014. An exploratory analysis of land abandonment drivers in areas prone to desertification. Catena. doi:10.1016/j.catena.2014.02.006

Lieskovsky, J., Kanka, R., Bezak, P., Stefunkova, D., Petrovic, F., Dobrovodska, M., 2013. Driving forces behind vineyard abandonment in Slovakia following the move to a market-oriented economy. Land use policy 32, 356-365. doi:10.1016/j.landusepol.2012.11.010

Łowicki, D., 2008. Land use changes in Poland during transformation. Case study of Wielkopolska region. Landsc. Urban Plan. 87, 279-288. doi:10.1016/j.landurbplan.2008.06.010

Milenov, P., Vassilev, V., Vassileva, A., Radkov, R., Samoungi, V., Dimitrov, Z., Vichev, N., 2014. Monitoring of the risk of farmland abandonment as an efficient tool to assess the environmental and socio-economic impact of the Common Agriculture Policy. Int. J. Appl. Earth Obs. Geoinf. 32, 218-227. doi:10.1016/j.jag.2014.03.013

Moreira, F., Russo, D., 2007. Modelling the impact of agricultural abandonment and wildfires on vertebrate diversity in Mediterranean Europe. Landsc. Ecol. 22, 1461-1476.

Mottet, A., Ladet, S., Coqué, N., Gibon, A., 2006. Agricultural land-use change and its drivers in mountain landscapes: A case study in the Pyrenees. Agric. Ecosyst. Environ. 114, 296-310. doi:10.1016/j.agee.2005.11.017

Munroe, D.K., van Berkel, D.B., Verburg, P.H., Olson, J.L., 2013. Alternative trajectories of land abandonment: Causes, consequences and research challenges. Curr. Opin. Environ. Sustain. 5, 471-476. doi:10.1016/j.cosust.2013.06.010

Navarro, L.M., Pereira, H.M., 2012. Rewilding Abandoned Landscapes in Europe. Ecosystems 15, 900-912. doi:10.1007/s10021-012-9558-7

Pazúr, R., Lieskovský, J., Feranec, J., Ot’ahel', J., 2014. Spatial determinants of abandonment of large-scale arable lands and managed grasslands in Slovakia during the periods of post-socialist transition and European Union accession. Appl. Geogr. 54, 118-128.

doi:10.1016/j.apgeog.2014.07.014

Pereira, H., Navarro, L., 2015. Preface, in: Pereira, H.M., Navarro, L.M. (Eds.), Rewilding European Landscapes. Springer Heidelberg New York Dordrecht London, pp. v-X. doi:10.1007/978-3-319-12039-3

Pointereau, P., Coulon, F., Girard, P., Lambotte, M., Stuczynski, T., Sánchez Ortega, V., Del Rio, 
A., 2008. Analysis of the Driving Forces behind Farmland Abandonment and the Extent and Location of Agricultural Areas that are Actually Abandoned or are in Risk to be Abandoned.

Prishchepov, A. a., Müller, D., Dubinin, M., Baumann, M., Radeloff, V.C., 2013. Determinants of agricultural land abandonment in post-Soviet European Russia. Land use policy 30, 873-884. doi:10.1016/j.landusepol.2012.06.011

Rey Benayas, J., 2007. Abandonment of agricultural land: an overview of drivers and consequences. CAB Rev. Perspect. Agric. Vet. Sci. Nutr. Nat. Resour. 2. doi:10.1079/PAVSNNR20072057

Rey Benayas, J.M., Martins, A., Nicolau, J.M., Schulz, J.J., 2007. Abandonment of agricultural land: an overview of drivers and consequences. CAB Rev. Perspect. Agric. Vet. Sci. Nutr. Nat. Resour. 2. doi:10.1079/PAVSNNR20072057

Sierra, R., Russman, E., 2006. On the efficiency of environmental service payments: A forest conservation assessment in the Osa Peninsula, Costa Rica. Ecol. Econ. 59, 131-141. doi:10.1016/j.ecolecon.2005.10.010

Terres, J.-M., Nisini, L., Anguiano, E., 2013. Assessing the risk of farmland abandonment in the EU. doi:10.2788/81337

Terres, J.-M., Scacchiafichi, L.N., Wania, A., Ambar, M., Anguiano, E., Buckwell, A., Coppola, A., Gocht, A., Källström, H.N., Pointereau, P., Strijker, D., Visek, L., Vranken, L., Zobena, A., 2015. Farmland abandonment in Europe: Identification of drivers and indicators, and development of a composite indicator of risk. Land use policy 49, 20-34. doi:10.1016/j.landusepol.2015.06.009

Tesfaye, W., Seifu, L. 2016. Climate change perception and choice of adaptation strategies: Empirical evidence from smallholder farmers in east Ethiopia. International Journal of Climate Change Strategies and Management, 8 (2), pp.253 - 270.

van der Sluis, T., Pedroli, B., Kristensen, S.B.P., Lavinia Cosor, G., Pavlis, E., 2015. Changing land use intensity in Europe - Recent processes in selected case studies. Land use policy. doi:10.1016/j.landusepol.2014.12.005

van Dijk, G., Zdanowicz, A., Blokzijl, R., 2004. Land abandonment, biodiversity and the CAP, Land abandonment and biodiversity, in relation to the 1st and 2nd pillars of the e $\mathrm{u}$ 's Common Agricultural Policy; outcome of an international seminar in Sigulda, Latvia, 7-8 October, 2004. Utrecht, Netherlands.

Vanwambeke, S.O., Meyfroidt, P., Nikodemus, O., 2012. From USSR to EU: 20 years of rural landscape changes in Vidzeme, Latvia. Landsc. Urban Plan. 105, 241-249. doi:10.1016/j.landurbplan.2011.12.009

Wunder, S., The Dung, B., Ibarra, E., 2005. Payment is good, control is better: Why payments for environmental services in vietnam have so far remained incipient, Cifor.Org. Bogor Barat, Indonesia. 
Zakkak, S., Radovic, A., Nikolov, S.C., Shumka, S., Kakalis, L., Kati, V., 2015. Assessing the effect of agricultural land abandonment on bird communities in southern-eastern Europe. J. Environ. Manage. 164, 171-179. doi:10.1016/j.jenvman.2015.09.005

Zaragozí, B., Rabasa, A., Rodríguez-Sala, J.J., Navarro, J.T., Belda, A., Ramón, A., 2012. Modelling farmland abandonment: A study combining GIS and data mining techniques. Agric. Ecosyst. Environ. 155, 124-132. doi:10.1016/j.agee.2012.03.019 
Table 1. General summary of the identified agricultural land abandonment drivers by their location according to the literature review

\begin{tabular}{|c|c|c|}
\hline Identified drivers & Country/ region & Source \\
\hline \multicolumn{3}{|l|}{ Socio-economic } \\
\hline $\begin{array}{l}\text { demographic trends and settlement pattern } \\
\text { (e.g. high emigration rate, rural population } \\
\text { change, elderly index, high average age of } \\
\text { residents) }\end{array}$ & $\begin{array}{l}\text { Slovakia; Ukraine; } \\
\text { Latvia; Mediterranean } \\
\text { region, Eastern Europe; }\end{array}$ & $\begin{array}{l}\text { (Pazúr et al., 2014); (Kanianska et al., 2014); } \\
\text { (Baumann et al., 2011); (Abolina and } \\
\text { Luzadis, 2015); (Kosmas et al., 2014); }\end{array}$ \\
\hline density of private economic entities; & Poland & (Łowicki, 2008) \\
\hline low yields and high cultivation costs; & Swiss mountains & $\begin{array}{l}\text { (Gellrich and Zimmermann, 2007); (Gellrich } \\
\text { et al., 2007) }\end{array}$ \\
\hline $\begin{array}{l}\text { agricultural market constraints (absence of } \\
\text { liberalized markets, market actions, an } \\
\text { unfavourable agricultural market) }\end{array}$ & $\begin{array}{l}\text { temperate European } \\
\text { Russia; Spain; } \\
\text { Slovakia }\end{array}$ & $\begin{array}{l}\text { (Prishchepov et al., 2013); (Corbelle-Rico et } \\
\text { al., 2015); (Lieskovsky et al., 2013) }\end{array}$ \\
\hline $\begin{array}{l}\text { economic and financial constraints (e.g. } \\
\text { economic activity of residents; the } \\
\text { financial inability of farmers; relative } \\
\text { decline of the agricultural income; } \\
\text { withdrawal of agricultural subsidies) }\end{array}$ & $\begin{array}{l}\text { Latvia; Slovakia; } \\
\text { Swiss mountains; } \\
\text { temperate European } \\
\text { Russia }\end{array}$ & $\begin{array}{l}\text { (Abolina and Luzadis, 2015);(Łowicki, } \\
\text { 2008);(Lieskovsky et al., 2013); (Gellrich et } \\
\text { al., 2007); (Prishchepov et al., 2013) }\end{array}$ \\
\hline $\begin{array}{l}\text { Accessibility (e.g. remoteness, distance } \\
\text { from roads, proximity to forest and shrubs, } \\
\text { distance from river, vicinity of large cities) }\end{array}$ & $\begin{array}{l}\text { France; Portugal; } \\
\text { Sweden; Spain; Latvia; } \\
\text { Slovakia; } \\
\text { Poland; Italy; Greece; } \\
\text { temperate European } \\
\text { Russia }\end{array}$ & $\begin{array}{l}\text { (Pazúr et al., 2014); (Beilin et al., 2014); } \\
\text { (Corbelle-Rico et al., 2012); (Bakker and } \\
\text { van Doorn, 2009); (Estel et al., 2015); } \\
\text { (Mottet et al., 2006); (Łowicki, 2008); } \\
\text { (Vanwambeke et al., 2012); (Prishchepov et } \\
\text { al., 2013) }\end{array}$ \\
\hline \multicolumn{3}{|l|}{ Ecological } \\
\hline $\begin{array}{l}\text { soil properties (e.g. soil quality, less fertile } \\
\text { soil) } \\
\text { rainfall seasonality; } \\
\text { vegetation properties (e.g. fraction of } \\
\text { brown vegetation cover, vegetation index) }\end{array}$ & $\begin{array}{l}\text { Portugal; Greece; } \\
\text { Mediterranean region, } \\
\text { Eastern Europe; Latvia; } \\
\text { Spain; Slovakia; } \\
\text { Ukraine; Bulgaria; } \\
\text { Swiss mountains }\end{array}$ & $\begin{array}{l}\text { (Pazúr et al., 2014); (Abolina and Luzadis, } \\
\text { 2015); (Abolina et al., 2015)(Bakker et al., } \\
\text { 2008); (Gellrich et al., 2007); (Kosmas et al., } \\
\text { 2014); (Baumann et al., 2011); (Milenov et } \\
\text { al., 2014); (Zaragozí et al., 2012) }\end{array}$ \\
\hline high/steep slopes; & $\begin{array}{l}\text { Slovakia; Spain; Italy; } \\
\text { Portugal; Ukraine }\end{array}$ & $\begin{array}{l}\text { (Pazúr et al., 2014); (Corbelle-Rico et al., } \\
\text { 2012); (Bakker and van Doorn, 2009); } \\
\text { (Bakker et al., 2008); (Cocca et al., 2012); } \\
\text { (Baumann et al., 2011) }\end{array}$ \\
\hline $\begin{array}{l}\text { geographical context; } \\
\text { Land fragmentation; }\end{array}$ & $\begin{array}{l}\text { Mediterranean region, } \\
\text { Eastern Europe; } \\
\text { Spain }\end{array}$ & $\begin{array}{l}\text { (van der Sluis et al., 2015); } \\
\text { (Kosmas et al., 2014); } \\
\text { Zaragozí et al.(2012) }\end{array}$ \\
\hline $\begin{array}{l}\text { small plot area; } \\
\text { the expansion of forest }\end{array}$ & Portugal; Sweden & (Beilin et al., 2014); \\
\hline
\end{tabular}

\section{Political}


policy obstacles(e.g. political actions, absence clear government policies) land-use policy (restitution of private property);
Mediterranean region, (Corbelle-Rico et al., 2015); (Abolina and Eastern Europe; Latvia; Luzadis, 2015); (Kosmas et al., 2014);

Spain

Slovakia

(Kanianska et al., 2014) 
Table 2. Summary of possible consequences of agricultural land abandonment

\begin{tabular}{|c|c|c|}
\hline \multirow[t]{2}{*}{ Effect } & $\begin{array}{l}\text { Possible consequence } \\
\text { Continuous abandonment }\end{array}$ & $\begin{array}{l}\text { Source } \\
\text { (Pazúr et al., 2014); }\end{array}$ \\
\hline & Increasing wildfire risks & (Beilin et al., 2014) \\
\hline \multirow[t]{3}{*}{ Negative } & $\begin{array}{l}\text { Decrease of traditional } \\
\text { farming, marginalisation } \\
\text { Changes in local economy }\end{array}$ & $\begin{array}{l}\text { (Corbelle-Rico et al., 2015); } \\
\text { (Kanianska et al., } \\
\text { 2014);(Mottet et al., 2006); } \\
\text { (Milenov et al., 2014) }\end{array}$ \\
\hline & $\begin{array}{l}\text { Loss of traditional } \\
\text { landscapes (cultural, high } \\
\text { nature value) }\end{array}$ & $\begin{array}{l}\text { van der Sluis et al.(2015); } \\
\text { Lieskovsky et al. (2013); } \\
\text { Cocca et al.(2012) } \\
\text { (Baumann et al., 2011) }\end{array}$ \\
\hline & $\begin{array}{l}\text { Outmigration from rural } \\
\text { areas }\end{array}$ & \\
\hline \multirow{5}{*}{ Positive } & $\begin{array}{l}\text { Re-vegetation (forest re- } \\
\text { growth, increase of woody } \\
\text { vegetation) }\end{array}$ & $\begin{array}{l}\text { (Zaragozí et al., 2012); } \\
\text { (Vanwambeke et al., 2012); } \\
\text { (Cocca et al., 2012); }\end{array}$ \\
\hline & Biodiversity loss & $\begin{array}{l}\text { (Corbelle-Rico et al., } \\
\text { 2015);(van der Sluis et al., }\end{array}$ \\
\hline & Soil erosion decrease & 2015);(Milenov et al., 2014) \\
\hline & $\begin{array}{l}\text { Pollution and sediment } \\
\text { export decrease from } \\
\text { agriculture }\end{array}$ & $\begin{array}{l}\text { (Bakker et al., 2008); } \\
\text { (Milenov et al., 2014) }\end{array}$ \\
\hline & $\begin{array}{l}\text { Bio- and renewable energy } \\
\text { potential }\end{array}$ & $\begin{array}{l}\text { (Estel et al., 2015); (Abolina } \\
\text { et al., 2015) }\end{array}$ \\
\hline
\end{tabular}




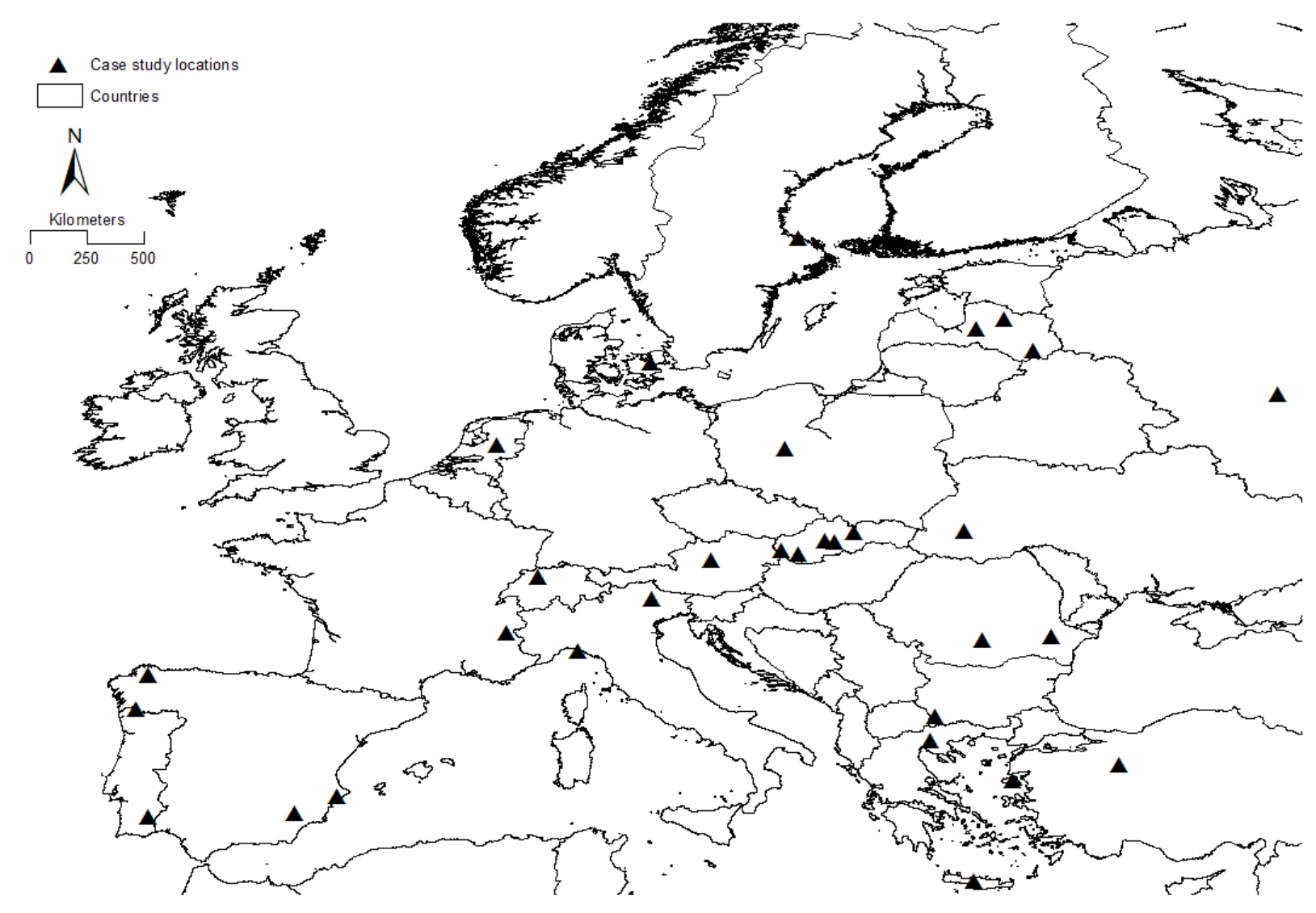

Figure 1. Location of case study areas. Large and medium scale studies are marked in the centre of this area 